\title{
cultivating oppositional debt ethics and consciousness: philosophy for/with children as counter-conduct in the neoliberal debt economy
}

\author{
jason thomas wozniak 1 \\ west chester university, united states of america \\ orcid id: https:/ / orcid.org/0000-0002-4092-7340 \\ “...poetry isn't a revolution but \\ a way of knowing \\ why it must come." \\ Adrienne Rich, Dreamwood
}

\begin{abstract}
In this article, I examine what the ethical and political implications of conceptualizing and practicing philosophy for/with children $(\mathrm{P} 4 \mathrm{wC})$ in the neoliberal debt economy are. Though P4wC cannot alone bring about any significant transformation of debt political-economic realities, it can play an important role in cultivating oppositional debt ethics and consciousness. The first half of this article situates $\mathrm{P} 4 \mathrm{wC}$ within the current global debt economy. Here, I summarize the analyses made by critical theorists of the ways that debt impacts public institutions (including schools), and shapes individual subjectivity. The second half of this article builds on Michel Foucault's conceptualization of "counter-conduct." For Foucault, counter-conduct is an ethical/political act of resistance against governmentality, one that makes possible alternative social relations and ways of being in the world. I argue in this section that $\mathrm{P} 4 \mathrm{wC}$ should be conceptualized, and practiced, as form of counter-conduct that challenges power in the debt economy. Both the form of $\mathrm{P} 4 \mathrm{wC}$ pedagogy, and the content that can be taken up in a collective manner in communities of inquiry, make $\mathrm{P} 4 \mathrm{wC}$ a potential site for debt counter-conduct practices. Thought of as counter-conduct, $\mathrm{P} 4 \mathrm{wC}$ is an educational practice with liberatory promise. I conclude this piece with brief ruminations on practicing $\mathrm{P} 4 \mathrm{wC}$ in the time of COVID, and during the uprisings around the world against racial capitalism. It is suggested here that $\mathrm{P} 4 \mathrm{wC}$ not only be practiced within formal education settings, but also in the social movements that are fighting to bring into being a world more just for all of us.
\end{abstract}

keywords: debt; philosophy for/with children (p4wc); counter-conduct

\section{cultivando la ética y la conciencia de la deuda de oposición: la filosofía para / con niños y niñas como contra-conducta en la economía de la deuda neoliberal}

resumen

En este artículo, examino cuáles son las implicaciones éticas y políticas de conceptualizar y practicar filosofía para / con niños y niñas $(\mathrm{P} 4 \mathrm{wC})$ en la economía neoliberal de deuda. Aunque $\mathrm{P} 4 \mathrm{wC}$ no puede provocar por sí sola ninguna transformación significativa en las realidades política-económicas de la deuda, puede desempeñar un papel importante en el cultivo de una

${ }^{1}$ E-mail: jwozniak@wcupa.edu 
cultivating oppositional debt ethics and consciousness: philosophy for/with children as counter-conduct in the neoliberal debt economy

ética y una conciencia de la deuda opuestas. La primera mitad de este artículo sitúa a P4wC dentro de la economía de deuda global actual. Aquí, resumo los análisis realizados por teóricos críticos sobre las formas en que la deuda afecta a las instituciones públicas (incluidas las escuelas) y configura la subjetividad individual. La segunda mitad de este artículo se basa en la conceptualización de la "contra-conducta" de Michel Foucault. Para Foucault, la contraconducta es un acto ético / político de resistencia contra la gubernamentalidad, que posibilita relaciones sociales y formas de estar en el mundo alternativas. Sostengo en esta sección que $\mathrm{P} 4 \mathrm{wC}$ debe conceptualizarse y practicarse como una forma de contra-conducta que desafía el poder en la economía de la deuda. Tanto la forma pedagógica de $\mathrm{P} 4 \mathrm{wC}$, como su contenido adoptado de manera colectiva en las comunidades de investigación, hacen de P4wC un sitio potencial para las prácticas de contra-conducta de la deuda. Pensada como una contraconducta, $\mathrm{P} 4 \mathrm{wC}$ es una práctica educativa con promesa liberadora. Concluyo este artículo con breves reflexiones sobre la práctica de $\mathrm{P} 4 \mathrm{wC}$ en la época de COVID y de los alzamientos en todo el mundo contra el capitalismo racial. Aquí se sugiere que P4wC no solo se practique dentro de los entornos de educación formal, sino también en los movimientos sociales que luchan por crear un mundo más justo para todos y todas.

palabras clave: deuda; filosofía para/con niños y niñas; contra-conducta.

\section{cultivando a ética e a consciência da dívida de oposição: filosofia para / com crianças como contra-conduta na economia da dívida neoliberal}

\section{resumo}

Neste artigo, examino quais são as implicações éticas e políticas de conceituar e praticar filosofia para/com crianças (FpcC) na economia da dívida neoliberal. Embora a FpcC não possa, por si só, trazer qualquer transformação significativa das realidades político-econômicas da dívida, ela pode desempenhar um papel importante no cultivo da ética e da consciência da dívida oposicionista. A primeira metade deste artigo situa a $\mathrm{FpcC}$ dentro da atual economia global da dívida. Aqui, somam-se as análises feitas por teóricos críticos sobre as maneiras como a dívida impacta as instituições públicas (incluindo escolas) e molda a subjetividade individual. A segunda metade deste artigo se baseia na conceituação de "contra-conduta" de Michel Foucault. Para Foucault, a contra-conduta é um ato ético/político de resistência à governamentalidade, que viabiliza relações sociais alternativas e modos de estar no mundo. Defendo nesta seção que $\mathrm{FpcC}$ deve ser conceituada e praticada como uma forma de contraconduta que desafia o poder na economia da dívida. Tanto a forma da pedagogia do FpcC quanto o conteúdo que pode ser abordado de maneira coletiva nas comunidades de investigação tornam o FpcC um local potencial para práticas de contra-dívida. Pensado como contra-conduta, o FpcC é uma prática educacional com promessa libertadora. Concluo este artigo com breves reflexões sobre a prática do FpcC na época do COVID e durante as revoltas ao redor do mundo contra o capitalismo racial. Sugere-se aqui que a $\mathrm{FpcC}$ não seja praticada apenas em ambientes de educação formal, mas também nos movimentos sociais que lutam para fazer nascer um mundo mais justo para todos nós.

palavras chave: dívida; filosofia para/com crianças; contra-conduta. 
cultivating oppositional debt ethics and consciousness: philosophy for/with children as counter-conduct in the neoliberal debt economy

\section{introduction}

I write this article from the city of Philadelphia, one of the poorest big cities in the richest country in the world, the United States. Here there are students who study, and teachers who teach, in schools full of poison asbestos, they drink contaminated drinking water, and the walls around them are crumbling. In the words of one teacherorganizer-hero, Jessica Way (2019), making students study in such conditions is tantamount to child-abuse. Many of the schools of Philadelphia are toxic and decaying because for decades, the schools have been underfunded, and the district is laden with debt.

This year alone, Philadelphia has set aside \$293 million dollars, or what amounts to nearly 10\% of its budget (Philadelphia School District 2019-2020 Adopted Operating Budget: Quick Budget Facts), to send to financial capitalists. This is a form of economic extraction. Money is extracted from the school system and accumulated by capitalist lenders. One must think about this. And when one does, one must ask: why are we sending millions of dollars to Wall Street when our kids are literally being poisoned, and forced to study in unsafe schools? Is this not a form of economic violence being waged against our youth? When the creditors demand that no matter the circumstances, they get paid, is this not a declaration of war against children, young adults, teachers, and against education? These questions are amplified now during a

period of COVID crisis. To quote the Institute for New Economic Thinking: "The world economy entered the COVID-19 pandemic with record debt levels. Since the global financial crisis, private and public debts have grown to more than $\$ 250$ trillion, about three times global GDP. With the current crisis, global debt will surge even further. This has deep implications for the way our economies, societies, and politics work" (2020). It has deep ramifications for education as well. Debt is a leading cause of austerity measures being imposed on education institutions around the world. Money that should be used to prevent teacher layoffs, provide education services like free 
cultivating oppositional debt ethics and consciousness: philosophy for/with children as counter-conduct in the neoliberal debt economy

internet to students, and keep everyone in school communities safe from the virus, is instead being used to pay debts.

Given the above, it seems not an exaggeration to say that we live in an era that calls on us to cultivate revolutionary thinking, make revolutionary demands, and participate in initiatives and movements that might lead to revolutionary transformations in society, and in the ways that we conceptualize and practice education. As educators committed to philosophy for/with children (P4wC) in both formal and informal learning spaces, we must ask what role education, and in particular, what role $\mathrm{P} 4 \mathrm{wC}$ has to play in developing the revolutionary subjectivities willing and able to make another world, in this world, possible. It seems to me prudent to remember, however, and here I think the epigraph by the feminist poet and radical educator, Adrienne Rich, is suggestive, that education, or the art of teaching and learning, of shaping personhood, and nurturing potentialities, is not necessarily revolutionary in and of itself. Paulo Freire, perhaps the most revered and well-known educator of revolutionary consciousness, seemed to tamper later in his life the expectations that education alone could bring about revolution, but also maintained that without education for critical consciousness, transformation is impossible, remarking that "though education may not be able to accomplish everything we wish, it is still a fundamental element in the re-invention of the world" (Freire, 2001, p.10). And that while it is true that "education is not the lever of social transformation, without it, no change is possible" (Freire, 2017, p.157).

Education, like poetry then, is a necessary but insufficient means of making us aware of why revolution is needed. Along these lines, and with the poetic verse of Rich in mind, I want to frame what ensues in the following way. Education in and of itself should not be confused with a revolution, and I would not consider P4wC to necessarily be a revolutionary pedagogical practice. But it often is, and certainly can be, a mode of inventing educational experiences that foster ways of knowing why revolution must come. Because of both the form it takes in practice: collective questioning of texts, dialogue in communities of inquiry, deep reflection exercises, etc., 
and the content it encourages us to philosophically examine, $\mathrm{P} 4 \mathrm{wC}$ can make possible, though without guarantees, new forms of knowledge production, unchartered social relations, and unique ways of living in the world. What themes and questions we take up in $\mathrm{P} 4 \mathrm{wC}$ communities of inquiry often makes the whole difference. How we practice $\mathrm{P} 4 \mathrm{wC}$, and what we collectively engage with in philosophical dialogue is not just a pedagogical, but also a political and ethical choice of great significance.

There is a long list of pressing issues that $\mathrm{P} 4 \mathrm{wC}$ practitioners might, and in some cases, do, concern themselves with. Global environmental devastation, racism, xenophobia, patriarchy, endless war, and the erosion of democracy in an increasingly authoritarian age, are just a few of the contemporary concerns that $\mathrm{P} 4 \mathrm{wC}$ helps us problematize. In this article, I want to focus on a structural political economy phenomenon, that to my knowledge, has not been explored within the $\mathrm{P} 4 \mathrm{wC}$ community. Here I will situate $\mathrm{P} 4 \mathrm{wC}$ within what some critical theorists refer to as the global neoliberal debt economy. The main reason for doing so is that today education takes place within, and is shaped by, the global debt economy. Moreover, as education conforms to the rules, regulations, logics, and ethics of the debt economy, it contributes to the formation of indebted subjectivity.

In this article, I concur with those like Maurizio Lazzarato, Étienne Balibar, Verónica Gago, Luci Cavallero, and David Graeber, along with many others, who critique debt as an apparatus that shapes and controls subjectivity on behalf of the interests of capital, and as a financial mechanism that hollows out democratic norms and practices. I argue that while P4wC certainly is not in and of itself capable of bringing about any sort of debtors' rebellion, or wide-scale debt jubilee, it most definitely can play an important role in making us realize why a debtors' revolution is needed. And it can contribute to the process of cultivating the type of oppositional debt consciousness and ethics found in the actors who will bring debt jubilee into being. Thought of this way, $\mathrm{P} 4 \mathrm{wC}$ is a poetic-political counter-conduct needed in formal and informal education spaces today. 
cultivating oppositional debt ethics and consciousness: philosophy for/with children as counter-conduct in the neoliberal debt economy

The central question that runs through this piece is: "What does it mean to practice P4wC in an era of neoliberal economic warfare?" Debt, Lazzarato (2015) has argued, lies at the strategic heart of neoliberal governance. It is not only the lifeblood of late stage neoliberalism, but also a weapon used to wage economic warfare on a variety of fronts, including in, and on, education. In the first half of this article I describe the debt economy in which all contemporary education institutions are situated, and all pedagogical practice unfolds. I also discuss how debt shapes individual subjectivity.

In the second-half of this article I assert that educators of all stripes have at their disposal means to counter the force of debt. Drawing on Michel Foucault, I discuss one of these by configuring $\mathrm{P} 4 \mathrm{wC}$ as a form of pedagogical counter-conduct within the debt economy. The article comes to a close with a brief rumination on how $\mathrm{P} 4 \mathrm{wC}$ can form people capable of contributing to existing contemporary debt resistance efforts, and why these movements should adopt and adapt $\mathrm{P} 4 \mathrm{wC}$ methodologies to advance their aims.

\section{brief remarks on neoliberalism}

I had the pleasure of delivering a draft version of this article at the XIX Conferencia Bienal de Filosofía para/con niños ICPIC -The International Council of Philosophy Inquiry with Children conference in Bogota, Colombia in July of 2019. ICPIC organizers rightly challenged conference participants to engage in a dialogue on what it means to theorize and do $\mathrm{P} 4 \mathrm{wC}$ in a globalized neoliberal world. It is not coincidental that the topic of neoliberalism and its influence on $\mathrm{P} 4 \mathrm{wC}$ was taken up in the Latin American Global South. Many of the first neoliberal experiments were conducted in countries like Colombia. And by now it is common knowledge that Chile served as a type of "blank slate" neoliberal fantasy land on which to test out neoliberal theory and practices developed in the United States (Harvey, 2007, pp.7-9).

Rather than provide an exhaustive literature review of the well-known critiques of neoliberalism, for our purposes here, it suffices to paint with broad strokes a generalized definition and summation of some of the ways neoliberalism has been 
problematized. ICPIC conference organizers, influenced in part by the work of Laverty and Gregory (2017, p. 525), astutely noted in the conference description that, "The twenty-first century has been marked by the rise of neoliberalism: an ideological commitment of the very privileged that defines, champions, and protects through violence, the notion of freedom as the pursuit of unexamined desires in a free-market economy, and which identifies individuals rather than communities as the sites of meaning and power" (International Council of Philosophical Inquiry with Children, Biennial Conference, 2019). Furthermore, they rightly claimed that "Education has largely been co-opted to serve this ideology, as it prepares students to adapt themselves to the wealth-obsessed, unjust and ecologically doomed environment of late capitalism" (International Council of Philosophical Inquiry with Children, Biennial Conference). A critique widely held of neoliberal ideology and policy is that it attempts to reduce all spheres of life, including education, to market logics (Brown, 2015). It radically de-humanizes subjectivity by postulating that individuals be conceptualized as human capital and micro-enterprises, and it leads to endless cycles of "accumulation by dispossession" (Harvey, 2007) in which formerly public goods are privatized. Moreover, neoliberalism, as Wendy Brown (2015) has convincingly shown, "hollows out" the very notion and practice of democracy. Public institutions are expected to adopt market logics; government is supposed to operate like a business enterprise, and people are encouraged to think of themselves first and foremost as human capital rather than citizens contributing to a collective democratic project (Brown, 2015). Debt plays a central role in intensifying the ways that neoliberalism shapes our institutions and lives.

\section{the neoliberal economy is a debt economy}

Moments of crisis have a way of revealing that which normally lies hidden. One of the outcomes of the 2008 financial crisis, which was largely caused by financial capitalist speculation, predatory lending, and eventual debt defaults, was the production of a vast amount of scholarship and analysis on financial debt. Since the 
cultivating oppositional debt ethics and consciousness: philosophy for/with children as counter-conduct in the neoliberal debt economy

crisis, a convergence around the idea that debt is at the heart of late-stage neoliberal capitalism has taken hold. Or as Maurizio Lazzarato (2012) has written, debt "represents the economic and subjective engine of the modern-day economy," and can be "conceived of and programmed as the strategic heart of neoliberal politics" (p.25). A complete literature review of critical approaches to debt scholarship falls outside the scope of this piece. Here I summarize main conclusions developed by three critical theorists of debt. Doing so helps us situate P4wC within the current political debt economy.

The global triumph of neoliberal debt ideology and policy has reduced both states and individuals to servants of financial institutions, according to Étienne Balibar (2013). Within the debt economy, financial institutions have acquired a tremendous degree of sovereignty over states. Today, Balibar (2013) demonstrates, it is possible to trace a direct correlation between the state's loss of power to regulate finance, and the increasing power of finance to control the state and dictate its policies. As Balibar (2013) writes, "having seized control at the same time of the resources of the state and of the citizens, the credit mechanisms which concentrate debts from all social actors have become in practice the 'regulators' of society." Within the current political economy, "States are permanently blackmailed by the financial markets" (Balibar, 2013). Monetary debt is a political weapon wielded by financial capitalists who hold state budgets and currencies hostage by demanding political and economic austerity reforms before granting credit. Nation-states are increasingly beholden to private financiers that demand pledges of debt payments in advance in the form of tax revenue (Balibar).

In fact, over the past 50-plus years nation-states (and municipalities) have become more and more dependent on debt financing to provide increasingly gutted and watered down public provisions. What has occurred, albeit it at different rates and with differing degrees of intensity, is that most of the world's nation-states have moved, according to Wolfgang Streeck (2017), from "tax states to debt states." Neoliberal ideology positions income and property taxation as a violation of individual 
freedom, and corporate taxation as a "job killer." Inspired by this anti-tax ideology, taxrevolts led by both individuals and corporations have led to significant reductions in tax revenue across the globe, but particularly in the United States (Streeck, 2017). The neoliberal austerity narrative has also convinced people that states spend too much on public goods, and that what is needed are drastic cutbacks to local and federal spending. Combined, the decrease in tax revenue, and the implementation of draconian austerity measures, has radically altered private and public life. Less public funding for public goods has meant that basic necessities for social reproduction like healthcare, housing, and education are increasingly funded by debt. Access to credit has been democratized, while debt-free access to necessities has been curtailed.

The implications of the expansion of credit markets and subsequent reliance on debt financing for mere survival has enormous implications for both states and individuals. I'll address the impacts on the latter shortly below, but here I want to momentarily discuss what Streeck has described as the transformation of the tax state into a debt state. This transformation has drastically transformed K-12 and higher education across the world.

Debt states, which today make up the majority of the world's nation-states, are states that cover most of their expenditures through borrowing rather than taxation (Streeck, 2017, p. 72). Entering a vicious debt/credit dependency cycle, these states, according to Streeck, accumulate mountains of debt that they have to finance with ever greater share of their revenues (pp. 72-73). Contrary to the austerity narrative that has economically and politically served the creditor class, states are not running deficits because of outlandish spending on public goods, rather, they face a revenue problem that is the result of years of lowering taxes on the wealthy. Or as Streeck (2017) writes, "Not high spending, but low receipts, are the cause of government debt" (p. 66 italics in original). What Streeck demonstrates throughout his Buying Time: The delayed crisis of democratic capitalism (2017), is that during the neoliberal era, governments have set limits to taxation that has disabled their ability to meet demands made of the postWWII welfare-state. Or put simply, tax revenue has lagged public spending, a result of 
cultivating oppositional debt ethics and consciousness: philosophy for/with children as counter-conduct in the neoliberal debt economy

decreased taxation of the rich (Streeck, p. 76). Tax cuts, expansion of credit markets, and increased reliance on debt financing has provided an economic handout to financial capitalists, and substantially augmented their political power.

The accumulation of wealth and power in the hands of financial capitalists during the period in which tax states have transitioned to debt states requires us to rethink our notions of democracy and sovereignty. That former chair of the United States Federal Reserve Alan Greenspan can matter-of-factly declare, without causing hardly a ripple of protest, that: "We are fortunate that, thanks to globalization, policy decisions in the US have been largely replaced by global market forces." And that, "National security aside, it hardly matters any difference who will be the next president. The world is governed by market forces" (Greenspan in Streeck, 2017, p. 85, emphasis added), is remarkable and gives credence to the claim that we live today under the power of what Andrew Ross (2013) adroitly calls the "creditocracy." Governance in the interests of the creditor class (re)produces a society where access to vital needs are financed through debt (Ross, 2013).

Streeck (2017) correctly notes that today more than ever it is necessary to think of the economy as politics, and economic forces as political forces (p. xv). Or put negatively, we "can't understand politics without relating them to markets" (Streeck, p. 1xiii). When one adopts this view, it becomes clearer that debt crises are the result of political decisions that benefit the creditor class. Importantly, we need also note that the political decisions that provoke debt crises are radically undemocratic. I hastily cite but three examples of anti-democratic debt governance at work on national, neocolonial, and municipal levels.

It seems hardly an exaggeration to state that we witnessed the death of democracy at the hands of creditors in the very place where democracy was born. The tragic irony of the Greek debt crisis (2009-Present) is that the people, the demos, voted against debt austerity in a 2015 referendum, and yet European Union banks, led by a German nation that still owes Greece reparations for WWII destruction, simply ignored the will of the people, and imposed draconian debt repayment programs on Greece 
that led to starvation, unemployment, and a ripping to shreds of the Greek social safety net. Not to be outdone by Western European economic heavyweights, in neocolonial fashion, the United States imposed the Puerto Rico Oversight, Management, and Economic Stability Act (PROMESA) on the Puerto Rican people soon after the Puerto Rican government declared that it couldn't pay down its $\$ 74$ billion debt. PROMESA authorizes a fiscal oversight board to make sure that Puerto Rico pays its debts, many of which are illegitimate. The people of Puerto Rico have very limited power over this board, and are essentially forced to accept fiscal decisions made by it. Of note within the context of this article, is the fact that at the time of this writing, the Puerto Rican debt crisis has led to 600 public schools being closed on the island during the last decade (Donnelly-Derovan, 2019), and drastic cuts to one of the best public university systems in the Global South (Brusi, Bonilla, and Godreau, 2018). And in 2013, when the city of Chicago decided to close 50 public schools to honor debt covenants written into the school district's annual budget, the city paid no attention to the protests of its citizens against the closures. It is fallacious and cynical therefore for the European Union to purport to be a democratic body while actively squashing democratic aspirations in countries like Greece, the height of hypocrisy for the "land of the free and the brave" to cower to creditor pressure and entrap the island of Puerto Rico in debt, and morally bankrupt for cities like Chicago to close schools in mostly Black and Latinx neighborhoods as they treat covenants made with creditors as more sacred than those with the people.

For good reason, debt is most often discussed in economic terms. Considering the above, it is clear, however, that debt should be analyzed in political terms as well. One way to conceptualize debt is as an economic agreement on a quantifiable amount of money that establishes an asymmetrical political relation. We have seen how this economic-political relation structures international relations and domestic governance. What need also be emphasized are the ways in which debt is an economic-political relation that shapes individual subjectivity as well. 
cultivating oppositional debt ethics and consciousness: philosophy for/with children as counter-conduct in the neoliberal debt economy

According to Maurizio Lazzarato (2012, 2013), who has perhaps more than anyone written on debt's influence on subjectivity, debt is a dispostif (apparatus). Responding to the fundamental problem of modernity: how to regulate a multitude of forces that act and react amongst each other, absent a single source of power (the sovereign), apparatuses are those things or assemblages that manage relations between forces that always involve a power relation (Lazzarato, 2002, p. 103). The debt economy consists of a heterogeneous set of elements that interact, creating and enforcing a variety of social relations, but also producing different ways that people think and feel about themselves. Most importantly, for the purposes of the current conversation, the debts we owe shape the way we behave, live our lives, conduct ourselves. Lazzarato (2012) expresses this clearly, "Unlike what happens on financial markets, the beneficiary as 'debtor' is not expected to reimburse in actual money but rather in conduct, attitudes, ways of behaving, plans, subjective commitments, the time devoted to finding a job, the time used for conforming oneself to the criteria dictated by the market and business, etc.," (p. 104, emphasis added).

Before providing a summative analysis of debt's formative force, I need note that at times Lazzarato, and others, myself included, have described indebted subjectivity in universal terms. This type of theoretical move is problematic when juxtaposed with the concrete experiences of debtors. Debt does not impact people in the same ways. Depending on a person's class, race, gender, ethnicity, and sexuality (we could add more identity traits here), debt has different effects on subjectivity. Or put another way, it is vitally important to analyze debt through an intersectional lens.

Two examples serve to justify this claim. Saidiya Hartman (1997) has masterfully demonstrated how an intersection of debt and educational projects were used to fabricate ex-slaves into indebted subjects after the American Civil War. According to Hartman (1997), for ex-slaves, emancipation did not mark the end of bondage; rather, it marked the beginning of an era of "indebted servitude" (pp. 125-126). Ex-slaves were denied land, fair labor opportunities, and subject to gratuitous violence sanctioned, and often performed by, the state. They were simultaneously forced into debt peonage, 
told incessantly that they owed a moral debt to the nation that had "freed" them, and taught, through the use of conduct books and other means, how to fulfill their debt obligations (Hartman, 1997). Former slave owners, northern industrialists, and liberal education reformers in the postbellum United States worked to guarantee that exslaves be "transformed into a rational, docile, and productive working class - that is, fully normalized in accordance with standards of productivity, sobriety, rationality, prudence, cleanliness, (and) responsibility" (Hartman, p. 127) so that they could efficiently and obediently serve their debts. Today, debt remains one of the many vestiges of the "afterlife of slavery" (Hartman, 2007) that haunts the United States.

Tragically, both debt and education intersect in a debt-education matrix that places African Americans, particularly women, in debt bondage. To note, 57\% of Black women in the United States who are paying their student loan debts have difficulty paying for essential services (American Association of University Women, 2017, p. 2) Moreover, it is worth noting again that the 50 public schools that were closed in Chicago, and in other urban centers this trend applies, so that the city could service its debt and appease credit rating agencies, mostly served Black, Latinx, and poor students.

Indebted life is not only racialized, but also gendered. Perhaps no scholars have made it clearer why debt is a gender, and by extension should be a feminist, issue than Luci Cavallero and Verónica Gago in their Una Lectura Feminista de la Deuda (2019). ${ }^{2}$ As the title of their book suggests, Cavallero and Gago provide a much-needed feminist reading of debt realities. Combining socialist feminist analysis on the impact of debt on social reproduction, along with anecdotes from indebted activists, the two authors demonstrate throughout their book that gender difference operates in distinct modes in relation to indebtedness. This is due to several issues, since that difference supposes:

1) a particular form of moralization directed toward women and feminized bodies;

\footnotetext{
2 I want to thank Liz Mason-Deese for providing me with her translations of Cavallero and Gago's work. The English version of Una Lectura Feminista de la Deuda is currently being produced and will be released in the spring of 2021.
} 
cultivating oppositional debt ethics and consciousness: philosophy for/with children as counter-conduct in the neoliberal debt economy

2) a differential of exploitation due to the corresponding relations of subordination;

3) a specific relation between debt and reproductive tasks;

4) the concrete impact of sexist violence, to which debt is connected; and

5) fundamental variations in the possibilities "for the future" involving financial obligations in the case of feminized bodies (Cavallero \& Gago, 2019).

With the above in mind, encapsulating key elements of Lazzarato's work, and drawing on my own anecdotal experience of organizing debtors with the Debt Collective, ${ }^{3}$ we can postulate four fundamental ways that the force(s) of debt shapes who we are, and who we may, or may not, become. For the sake of clarity and brevity, I will analytically separate the ways in which debt influences subjectivity, but the reader should remember that functioning as an apparatus, debt's heterogenous subjectivation forces intersect, often acting in unison on personhood.

We begin with the relation between debt and work. Debt imposes labor, or if one prefers, the indebted subject must constantly be at work to serve debts. Not only must the debtor constantly employ herself with wage labor, but also, she must constantly work on herself to form herself as human capital capable of competing for wages in the market place. To rest is to risk missing debt payments, and to miss debt payments is to risk a host of punitive measures.

Moreover, in neoliberal debt states that have hallowed out or eliminated public goods, if one wants to avoid personal household debt one must cultivate their human capital to avoid taking on debt for basic needs like food, health care, education, and housing. One might go deeper into the analysis of how debt and labor are conjoined by pointing out that debt is an apparatus that captures and controls both potentiality and impotentiality. On the one hand, the debtor (or the person trying to stay out of debt) must harness their potentiality and mold it into the capacities that will allow them to earn wages for debt repayment. On the other hand, the indebted subject, unlike

\footnotetext{
${ }^{3}$ During Occupy Wall Street in New York City and till today, I have collaborated with the Debt Collective on a variety of popular education projects. Most recently, I am one of the co-coordinators of a local chapter of the Debt Collective in Philadelphia. For more information on the Debt Collective, see: debtcollective.org.
} 
Melville's fictitious character Bartleby the Scrivener, cannot proclaim: "I prefer not to." They may not prefer it, but they do have to constantly work to pay off debts, otherwise, and maybe this is the untold story that explains Bartleby's fate, they face dire consequences.

Debt not only exploits the indebted subject's labor power, but also robs her time. Stated in basic terms, debt negates leisure time. Forced to constantly work in service of debt, the indebted subject has to relinquish her leisure time. While one could argue that in some cases debt allows one to "purchase" leisure time, think for example of a vacation paid for with a credit-card, it would be more accurate to say that in this case leisure time is borrowed time. Or in other words, the indebted vacationer will eventually have to account for the vacation time through future work. This labor time, it is worth noting, will be compounded because of interest accrued on the original debt. Further, building on the analysis of George Caffentis (2016), who convincingly argues that time colonized by debt is estranged time, the indebted vacationer runs the risk of having an alienating vacation experience if she is not able to temporarily (at least) forget that her present leisure time will soon compel her to take on increased future work.

Stated in general terms, debts accumulated in the past demand that we occupy our present with labor, and they often taint our experience of the present with guilt and/or anxiety. During the moments where we suspend labor in service of debt, we run the risk of not being able to fully enjoy the work-free present because of anxiety about the future to come, or guilt about purchases past. We can also state that our debts both colonize and foreclose on our future. Future debt payments always already await the indebted subject. These payments-to-come delimit how the future can, and will, be lived. The temporality of debt is not, therefore, linear. Rather, debts accumulated in the past that cannot be immediately serviced in the present, end up occupying the future. We might say that these future debts travel back in time to haunt the present that is occupied with labor for a wage that is earmarked for an indebted time to come. 
cultivating oppositional debt ethics and consciousness: philosophy for/with children as counter-conduct in the neoliberal debt economy

But it is perhaps debt's impact on the rhythms of our daily lives, more so than its ability to appropriate our time, that gives it its force in shaping indebted subjectivity. If we concur on a basic definition of rhythm, that it is repetition of movement in time, and we keep in the back of our minds the ancient Greek notion of rhuthmus, that is, rhythm as form, as that which gives shape, then we can state that debt's formative force lies in its ability to produce the rhythms of daily life. The repetition of these indebted life rhythms, i.e., the rhythms of labor to serve debt, have a substantial effect on shaping our personhood. In short, debt demands rhythms of service/labor which give form to daily life; our daily lives shaped by debt rhythms influence the production of indebted subjectivity (Wozniak, 2017).

Debt also shapes our interactions with others. The relations between individual creditors and debtors are nearly always asymmetrical. The creditor holds power over the debtor; the debtor must meet the demands of the creditor. Relations between debtors themselves are also shaped by the debts they owe. Debt intensifies the competitive drive of debtors who are forced to compete against each other on the job market for limited resources needed to repay debts. Moreover, debtors engage in cost/ benefit calculative thinking when making decisions about who to spend their time with, and how much time and effort they should put into developing sustained relationships. Or in other words, debtors make decisions about relationships with others based on debt inspired return on investment (ROI) logics. Finally, debtors give value to themselves and others based on the amount of debts owed, how they were accrued, and whether debts are paid back. A type of debtor moralizing manifests as debtors pass judgments on each other about debt. Internalized dominant ethical frameworks often produce feelings of guilt, shame, and ideas of success and failure.

It is worth pausing here to analyze debt in ethical terms by drawing on the work of Argentine philosopher, Enrique Dussel. One of the central arguments made across Dussel's work is that systems and forms of domination which negate life are evil (2013, p. 212). Such systems and accompanying forms of domination produce what Dussel calls "victims," a term he uses throughout his oeuvre to describe those whose life is 
constantly threatened with extinction or exploitation. When debt imposes labor, robs time, and leads to moralizing judgements of others and self that ultimately serve creditors, it negates the full flourishing of human life. It produces victims, and makes the reproduction of a life of dignity impossible for millions of people.

The production by, and existence within the debt economy, of the victim reveals the immorality of the system that produces her. Thought of this way, the production of the debtor is, in Dusselian terms, "a material refutation or falsification of the truth of the system that produces such victims" (2013, p. 282). The problem, however, is that the debt economy is generally affirmed as just and legitimate according to contemporary neoliberal logics and ethics. As such, rather than reflect critically and ethically on the ways that debt negates life, the negation is accepted, unquestioned, and affirmed by a majority of people. Through various ideological state apparatuses like schools, the church, media and family, people are taught that debt obligations to private creditors are sacred covenants that cannot, under any circumstances, be broken. Debtors and non-debtors alike believe that there are moral obligations to serve debts. Hence an ethics of debt, which in Dusselian terms would qualify as an "ethics of domination," contributes to the reproduction of material conditions that favor creditors and produces debtor-victims.

Domination by debt is of course nothing new, nor unique to the current neoliberal era we are living in. The anthropologist David Graeber's masterpiece on debt, Debt: The First 5,000 Years (2012), is testament to the age-old relation between debt, dominion and violence. And as people living in the Global South can attest to, debt has long been used as a neocolonial tool of oppression used by imperial powers of the North to both control, and extract plunder, from Global South countries and peoples. Many years before the current debt crisis hit both the Global North and South during the Great Recession of 2008, Dussel himself wrote a brief rumination on the ways in which debt is weaponized.

In a chapter titled, "International Loans and Weaponry" found in his Ethics and Community (1988), Dussel argues that both debt and weapons are "two types of 
cultivating oppositional debt ethics and consciousness: philosophy for/with children as counter-conduct in the neoliberal debt economy

investment that reproduce not life, but death" (p. 158). Drawing on a variety of sources, including Marx and Aristotle, he notes that financial capital is the creation of money by money, a process which is not natural, and which leads to all wage-earner's surplus life being robbed by capital (Dussel, 1988). Capital is presented here not only as a "god, representing itself as having proceeded from nothing (ex nihilo)," but as the "new Moloch." (1988, pp. 160-161).

Debt-as-Moloch demands sacrifice. Citing Mexican debt-service requirements in 1984, Dussel (1988) notes that Mexico was to pay $\$ 12$ billion in annual interest while the average Mexican worker earned about a dollar a day that year. He writes, "Twelve billion human 'life-hours'! A half-million persons sacrificed annually to the god of Moloch (calculating the average working life of a laborer at eight hours a day for fortyfive years to support a family of four)" (p. 163). Considering the P4wC context of this article, we should recall that Moloch was an ancient Canaanite deity that demanded child sacrifice. Debt-as-Moloch not only robs adult life, it demands that children are sacrificed to it.

Upon finishing Dussel's chapter one comes to clearly see how financial capital finances various forms of warfare and weaponry. Often, this weaponry is used to "protect" the interests and investments of the Global North and their accomplices in the Global South. But it is also used to threaten, or as a way to impose, austerity. One must wonder, then, why Dussel chose to title his chapter "International Loans and Weaponry," (Créditos internacionales y armamentismo) instead of "International Loans as Weaponry." For clearly, in the hands of the capitalist elite, debt is a weapon of mass destruction, waged primarily on the poor, and especially on our children.

Our children suffer through an ongoing economic war in the debt economy. Schools are underfunded, collapsing, toxic, or over crowded because states and cities are obliged to honor debt covenants with creditors rather than invest in infrastructure. Teachers and school staff often carry multiple forms of debt, and are paid insufficient wages in part so that Wall Street firms that hold school debt bonds can handsomely reward shareholders with high dividends. Rather than pay teachers just wages, we pay 
bond holders high dividends. And as preposterous as it may sound, in the richest country in the world, the United States, thousands of children are saddled with school lunch debts. Here in the U.S. we deny poor children who carry "lunch debts" a decent meal at school rather than confront creditors who siphon off school funding resources for their own profit (Rizzo, 2019). These attacks on education are "justified" through the discourse, logic, and ethic of austerity. Losses are socialized, gains are privatized. Our children's education, and sometimes their lives, are sacrificed to debt.

Given all the above, it seems urgent to ask: "What does it mean to practice P4wC when the walls of debt-laden schools are collapsing or coated in toxic paint, when teachers are stressed and haunted by precarity because their wags are stagnant and their debts piling up, when public schools are shuttered to service creditors, when students go hungry, because creditors have their foot on the necks of their parents, when the future of our children is already foreclosed by debt?" Asking the questions raised above also forces us to take up this question: "How might PW4C be an educational practice that not only negates the force of debt, but also opens up the possibilities for debt rebellion and debt jubilee on a global scale?" It is to this latter question, and others related to it, that we now turn our attention.

\section{p4wc as counter conduct in the debt economy}

Since its inception, $\mathrm{P} 4 \mathrm{wC}$ practitioners have demonstrated beyond refute that the virtues of $\mathrm{P} 4 \mathrm{wC}$ are wide-ranging. As an educational practice, it is a means of cultivating democratic and moral individuals. It cultivates critical, aesthetic, and ethical ways of thinking in community. And it produces radical ruptures of chronological temporalities, often structured according to the needs of capitalist production (Kennedy \& Kohan, 2014). There have been some important discussions and efforts to link P4wC with critical theory, and conceive of it as a form of critical pedagogy (Gregory, 2011). Surprisingly, however, there is sparse scholarship about the 
cultivating oppositional debt ethics and consciousness: philosophy for/with children as counter-conduct in the neoliberal debt economy

ways in which $\mathrm{P} 4 \mathrm{wC}$ might provide an educational theory framework, and practice, capable of negating popular neoliberal education reforms and their effects. ${ }^{4}$

We are not born as racists, misogynists, or xenophobes. Nor are we, in spite of whatever pseudoscience social Darwinists bombard us with, born capitalists, or as neoliberals. Capitalist subjectivity, and by extension, neoliberal subjectivity must be cultivated; it must be trained, disciplined. How P4wC across the world is complicit in said training, is worthy of a long debate, but not the focus of the present article. Here, building on the premise already hinted at above, that children are thrown into a debt economy from birth, and that over time they become indebted subjects, I want to argue, inspired in part by Marx's (1845) famous dictum, "Philosophers have hitherto only interpreted the world in various ways; the point is to change it." that $\mathrm{P} 4 \mathrm{wC}$ be a means by which we come to a better interpretation of the debt economy, and also that it serves as a manner to intervene in it. Individual debt resistors need be formed, a collective debt resistance movement cultivated. There are many political education processes that might cultivate a debt resistor, foster debt resistance. What I'm suggesting here, is that $\mathrm{P} 4 \mathrm{wC}$ be considered one of these. Situating $\mathrm{P} 4 \mathrm{wC}$ as an oppositional practice, one which is a form of resistance to debt governance, can be done by conceptualizing and practicing it as what Foucault called "counter-conduct."

While it is often Foucault's work on governance that garners the most attention, his work on counter-conduct is less known, and often overlooked. We pay both an analytical, and social movement/ political price for doing so. Arnold Davidson (2011) has written that "counter-conduct" is a "a conceptual hinge, a key concept, that allows us to link together the political and ethical axes of Foucault's thought" (p. 26). This concept allows Foucault to analytically move between "the quite specific form of power that takes as its object the conduct of individuals to the correlative counter-movements that he initially designates as specific revolts of conduct" (Davidson, 2011, p. 27). It can

\footnotetext{
${ }^{4}$ While I by no means conducted an exhaustive search, I did review some of the most widely-read P4wC journals in English, Spanish and Portuguese and was surprised at the lack of interest by scholars of the field in neoliberalism. The words "neoliberalism" and "neoliberal" appear sparsely in word searches of the referred to journals.
} 
be said that if governance, or conduction, is simultaneously a negation of freedom, and a production of a type of subjectivity, then counter-conduct is a negation of the negation that invents possibilities for other ways of being in the world.

Foucault devoted an entire lecture to counter-conduct on March 1st, 1978 at the Collège de France. His pedagogy during this lecture is stellar. He begins first by leading his audience to an understanding of conduct by tracing the term's etymological roots to the Greek "oikonomia psuchon," the economy of souls (Foucault, 2007, p. 192). We learn here that the Latins later translated this term as "regimen animarum, 'government or regimin (réme) of souls'" (p. 192). By the late $16^{\text {th }} /$ early $17^{\text {th }}$ century the word "conduct" (conduite) is in use, and Foucault states that it refers to two things: "Conduct is the activity of conducting (conduire), of conduction (la conduction) if you like, but it is equally the way in which one conducts oneself (se conduit), lets oneself be conducted (se laisse conduire), is conducted (est conduit), and finally, in which one behaves (se comporter) as an effect of a form of conduct (une conduite) as the action of conducting or of conduction (conduction)" (p. 193).

Conduct thus is both something that an external force imposes on someone, and a practice, or way of being that a person takes on herself. Having established the meaning of conduct, Foucault then turns the rest of his lecture into an exploration into the ways in which conduct/conduction can be countered. Focusing on actors/movements that had as their objective the cultivation of different varieties of conduct that challenged pastoral power, Foucault (2007) develops a notion of counterconduct as a "form of resistance to power as conducting" (p. 195). Importantly, though Foucault focused this particular lecture on counter-conduct against pastoral power, he makes it clear that because counter-conduct is something that always emerges in correlation with forms of dominance, it is a practice that can be applied within a variety of contexts, and at different historical moments.

At its most basic level, counter-conduct is an attempt to "escape direction by others and define the way to conduct oneself" (Foucault, 2007, p. 195). While it is a refusal of conduction, and a revolt against a force relation, it is not a practice that seeks 
cultivating oppositional debt ethics and consciousness: philosophy for/with children as counter-conduct in the neoliberal debt economy

or achieves some sort of pure autonomy. Counter-conduct is not a chaotic practice that seeks to elide any form of direction, objectives, or conduction. Rather, counter-conduct is a material manifestation of oppositional consciousness that resists particular power relations: "We do not wish to obey these people. We don't want this truth. We don't want to be held in this system of observation and endless examination that continually judges us, tells us what we are in the care of ourselves" (Foucault, p. 201, emphasis added). Put positively, and in interrogative form, counter-conduct refuses one form of conduction in favor of another, one that is individually or collectively determined: "By whom do we consent to be directed or conducted? How do we want to be conducted? Towards what do we want to be led" (Foucault, p. 197)? In sum, counter-conducts always contain "an aspect of the pursuit of a different form of conduct: to be led differently, by other men, and towards other objectives than those proposed by the apparent and visible official governmentality of society" (Foucault, p. 199).

It is worth noting that Foucault (2007) almost reluctantly settles on the word "counter-conduct" to describe the type of challenges to governmentality he fleshes out. He rejects the term "revolt" because it is "both too precise and too strong to designate much more diffuse and subdued forms of resistance" (p. 200). Decides against "disobedience," because it is "too weak" a term, and one that doesn't capture the productive element of counter-conduct (p. 200). For political and historical reasons related to the Soviet Union and the Communist Party, he rejects the term "dissidence" (pp. 200-201). And prefers "counter-conduct" over "misconduct" because the latter "only refers to the passive sense of the word, of behavior: not conducting oneself properly" (p. 201).

More important than naming the action, is being able to state clearly what the action does. With Foucault's assistance we can sum up the effects of counter-conduct in the following way. Counter-conduct puts into question, works on, and erodes power (Foucault, p. 202). It is an action and way of being that reverses, nullifies, and discredits governmentality, and thus redistributes power (Foucault, p. 204). Doing so, it creates the possibilities for a new form of conduction, and thus a new form of living in the 
world. Thus, counter-conduct simultaneously negates power, and invents positive alternatives for different modes of relationality and subjectivity. Counter-conduct enlarges the possibility of being something other than what power wants us to be.

Foucault (2007) wraps up his lecture with brief descriptions of five forms of counter-conduct in the Middle Ages. For the sake of brevity, I will only list them here. Asceticism was a counter-conduct exercise "of the self on the self," a type of individual spiritual exercise. The formation of communities that produced events and rituals like carnival was another way of refusing submission to pastoral power. Mysticism, the third conduct highlighted by Foucault, allowed the mystic to escape examination by an external source, cut out the pastoral "middle-man" or the Church, and hence made possible a one-to-one relation with God. Counter readings of scripture, the fourth example, were spiritual acts used to "short circuit" the pastorate (p. 213). And finally, the fifth element involved a challenge to traditional eschatological beliefs.

Practices of counter-conduct are tactics of resistance that work within, while challenging, dominant systems of power. What I want to argue here, is that $\mathrm{P} 4 \mathrm{wC}$ can be, and in some cases already is, because of its methodology, a form of counter-conduct practiced with children, but also adapted for adults, in the debt economy. P4wC experiences can suspend the force of debt on our subjectivity, and open possibilities to be/become something other than an indebted subject. We might put it this way: P4wC can be practiced as a conduct which runs counter to the force of debt that leads us to conduct our lives in line with the norms, regulations, ethics, and laws of contemporary indebted life. $\mathrm{P} 4 \mathrm{wC}$ experiences provide an occasion to say that we do not wish to obey the people that run the debt economy. We do not want to abide by their truths. And we demand a radical break with their systems of observation and surveillance (think here of credit reports, credit ratings) that continually judge us, and give value to our lives based on market metrics.

Further, P4wC experiences offer an opportunity to refuse conduction by debt, and replace it with other conducts, democratically and deliberately decided upon, in communities of inquiry. Thought of this way, a P4wC experience would first, and 
cultivating oppositional debt ethics and consciousness: philosophy for/with children as counter-conduct in the neoliberal debt economy

possibly foremost, provide a rhythmic rupture within everyday indebted life. And within the rhythmic caesura, questions central to counter-conduct could be put on the table for discussion: "Do we consent to be directed or conducted by debt?" "Should our conduct be shaped by the debts we, or our nation, city, state, owes?" "If we reject the force of debt, towards what do we want to be led?" Not only would the questions presented, but also the content of $\mathrm{P} 4 \mathrm{wC}$ dialogues themselves be based on debt realities. Finally, within the break from the rhythms of indebted life a new ethics might be fostered and nurtured. An ethics in which those in the community of inquiry decide that the only debts and obligations that they have are to each other, their loved ones, and their friends, not banks or creditors.

To reiterate, for Pw4C to function as debt counter-conduct there are both methodological and content considerations to keep in mind. The methodology of $\mathrm{P} 4 \mathrm{wC}$, its emphasis on building cooperative communities of inquiry, the centrality of questions/questioning, the collective examination of texts, etc., are conducive to debt counter-conduct. They help build bonds between participants that transcend the logics and ethics of financial debt contractual relationships. The nature of $\mathrm{P} 4 \mathrm{wC}$ dialogue is also radically different than the types of discussions that occur between creditors and debtors. Here, dialogue occurs (ideally) amongst equals, whereas discussions between creditors and debtors is typically asymmetrical. And of course, the wide range of questions, and the practice of questioning, that $\mathrm{P} 4 \mathrm{wC}$ promotes is not to be found in creditor-debtor relations. Creditors often dictate terms of debt contracts to debtors; these contracts are almost never open to questioning and debate.

Moreover, adopting a flexible concept of what counts as a philosophical "text" for examination, one which would include anything (photography, poetry, painting, testimony, etc.,) that is up for philosophical questioning and interpretation, allows us to imagine how the content of $\mathrm{P} 4 \mathrm{wC}$ experiences can deal with a variety of realities related to the debt economy. Here we might suggest in Freirean (1989) terms, that those involved in $\mathrm{P} 4 \mathrm{wC}$ experiences pertaining to debt are given an opportunity to learn to read the world through the lens of debt. Once one begins to read the world this way, 
one begins to ask questions like: "Why is my school being closed when people in my community still need education?" "Is it fair that my classmates and I don't have enough text books?" "How come mommy and daddy need to work all the time, what does that mean for our family?" "Why are some of my friends being denied a school lunch?" Reading the contemporary world through the lens of debt, $\mathrm{P} 4 \mathrm{wC}$ communities of inquiry can arrive at an endless amount of ways to problematize the debt economy.

Taken together, when P4wC assumes the form of debt counter-conduct, and when it takes up the debt economy and indebted life as its content of study, then the practice can play a vital role in revealing the ways in which the debt economy is exploitative, and how it negates life and produces victims. Just as importantly, through both its form, and its content, $\mathrm{P} 4 \mathrm{wC}$ fosters possibilities for imagining alternatives to the debt economy; it grants participants a moment to live as someone other than an indebted subject, and allows them a chance to challenge, or decide to reject, the indebted life.

Recognizing once again that the debt economy has most perniciously impacted the lives of historically marginalized populations of the Global South, I want to suggest here that forms of counter-conducts practiced by these groups of people, specifically against debt, should be centered in $\mathrm{P} 4 \mathrm{wC}$ debt counter-conduct experiences. The notion of the Global South at work here is based on Boaventura de Sousa Santos' (2016) definition which reads:

The global South is not a geographical concept, even though the great majority of its populations live in countries of the Southern hemisphere. The South is rather a metaphor for the human suffering caused by capitalism and colonialism on the global level, as well as for the resistance to overcoming or minimising such suffering. It is, therefore, an anti-capitalist, anti-colonialist, anti-patriarchal, and antiimperialist South. It is a South that also exists in the geographic North (Europe and North America), in the form of excluded, silenced and marginalised populations, such as undocumented immigrants, the unemployed, ethnic or religious minorities, and victims of sexism, homophobia, racism and islamophobia (pp.18-19).

Centering here denotes at least two things. First, it means incorporating into $\mathrm{P} 4 \mathrm{wC}$ to the fullest extent possible, the epistemologies of the South that have 
cultivating oppositional debt ethics and consciousness: philosophy for/with children as counter-conduct in the neoliberal debt economy

historically been marginalized. This would involve not only the use of texts produced from Global South authors, but also, the lifting up of suppressed epistemological, ethical, and ontological frameworks during $\mathrm{P} 4 \mathrm{wC}$ dialogues. Secondly, there is a long history of different individuals and groups in the Global South that have resisted debt in a variety of counter-conduct manners, through praxis. The El Barzon peasant debt revolt in Mexico (Caffentzis, 2013), the daily (wayward) experiments in "living otherwise" of early-20th century Black women on the east coast of the United States beautifully documented in Hartman's Wayward Lives, Beautiful Experiments (2019), and current feminist debt resistance direct actions documented by Cavallero and Gago (2019) in Argentina, are but three of innumerous examples to draw inspiration from. The testimonies from these debt resistors can serve as starting points from which to build debt oppositional consciousness, ethics, and praxis in communities of inquiry.

I can imagine many objections to the proposition that $\mathrm{P} 4 \mathrm{wC}$ be conceptualized and practiced as a form of counter-conduct to indebted life. I would, however, like to offer a cursory response to one obvious concern: that kids and young adults should not be exposed to debt realities that they either don't have any direct influence on, or that they couldn't quite possibly understand. Here I turn to Ann Margaret Sharpe's (2009) ruminations on the "child as critic." Sharpe reminds us that, "To do philosophy well in a classroom community of inquiry is to engage in social criticism" (p. 207). In our case, doing philosophy well would entail either a direct critique of the debt society, or nurturing the capacity to do so. She also argues convincingly that, "Learning to practice social critique is not only a political and social endeavor, but a moral and aesthetic one" (p. 202). Thought of this way, $\mathrm{P} 4 \mathrm{wC}$ is one of a variety of ways in which participants can learn to delegitimize dominant debt ethics. $\mathrm{P} 4 \mathrm{wC}$ is in the end for Sharpe, a means by which children learn to publicly criticize, detect, and question dubious reasons and assumptions (p. 203), while at the same time nurturing an ethic of care for others, as well as a commitment to action. In short, communal philosophical inquiry carves out time in the global debt economy in which children (and adults) can uncover the forces that negate human flourishment, and imagine, invent, and practice a more humane 
way of being in the world. And it is for this reason that it can play such a vital, albeit it small, role in leading to the dismantling of the neoliberal debt economy.

\section{conclusion}

Any individual with debt, or any city, state, or country for that matter, knows that in isolation it is next to impossible to challenge the power of creditors. This is a truism throughout time and place, one that today more than ever is felt by debtors around the world. The need for a debtors' movement, now during the COVID 19 health and economic crisis, is more urgent than ever. The etymology of the word "apocalypse" comes from Greek apokalyptein and means, "to uncover, reveal." What COVID has revealed and made clearer, is what people dealing with debt have long felt: capitalism, and the debt economy that sustains it, is a virus that takes over and kills the people and places it inhabits. As COVID spreads, impoverished family households and countries of the Global South are being forced into similar no-win situations. They are forced to choose between paying their creditors, or supplying their loved ones and denizens with the healthcare and basic necessities needed to survive the current catastrophe. Once again, as always, those who are suffering most from the crisis co-produced by COVID and the debt economy, are the historically marginalized: women, the poor, Black, Indigenous, and other non-white populations. Debt burdens, coupled with COVID, and state violence against those who try to struggle within and against the oppressive racialized and gendered order of things, are quite literally leading to sometimes slow, sometimes swift, asphyxiation.

When I began this piece, COVID was just emerging in China. As I finish it, in the United States we are in the midst of one of largest uprisings in the nation's history. Led by the Black Lives Matter movement, millions of people are taking to the streets to protest the murders of George Floyd, Breonna Taylor, Ahmaud Arbery, Tony McDade, and countless other innocent Black people. It bears noting that George Floyd was initially arrested, and then killed, for purportedly trying to use a counterfeit $\$ 20$ bill to buy some items at a shop in Minneapolis, Minnesota. I can't help but wonder two 
cultivating oppositional debt ethics and consciousness: philosophy for/with children as counter-conduct in the neoliberal debt economy

things. What economic conditions drove Floyd to allegedly counterfeit twenty-dollars? Was Floyd trying to survive on a limited and stagnate income? Was he in debt? Had all his access to credit dried up? Secondly, as Derrida (1994) pointed out quite some time ago, financial capital has no substance, it is not backed by gold, or any other material object. It is an essence, counterfeit money (Derrida, 1994). And yet, where are the authorities to arrest those who move trillions of counterfeit currency from one bank to another, enriching each other along the way, impoverishing the majority, and making it clear that in the debt economy, only certain lives matter? The murder of Floyd and countless other Black and Brown people around the globe, and the accumulation of wealth via debt extraction principally conducted by White upper-class businessmen, heightens the need to overturn neoliberal racial capitalism, to free billions from the bonds of debt.

The only hope for debt jubilee, however, depends on whether debtors can unite into a collective force capable of breaking free from the chains of debt that shape and control so much of our lives. Put simply, to challenge the laws, institutions, people in power, ideologies and ethics of the contemporary neoliberal debt economy, we need a mass organized movement of debtors. On local levels, the formation of debtors' unions would grant debtors the power to not only negotiate debt (credit) conditions, but also push for debt cancellation. ${ }^{5}$ Internationally, there exists an urgent need to add to the ranks of already existing debt jubilee initiatives, to unify analysis, tactics, and strategy.

It is worth stating in plain terms that ultimately, the struggle to transform the debt economy is a struggle to transition out of capitalism and into socialism. Or if you prefer, a shift from serving banks/creditors and the owners of capital to a political economy in which workers and (former) debtors own, and democratically manage, the banks and means of production. In this regard, debt jubilee demands, and the movements that make, and carry such demands out, are transitional movements making transitional demands. The end of the debt economy as we know it should not

\footnotetext{
${ }^{5}$ The Debt Collective is currently in the midst of building a national debtor's union with chapters spread out across the country.
} 
therefore be the end of revolutionary aims. It is but one transformative reform on the road to a larger restructuring of political economy and society.

To say that we are far from either mass debt jubilee, or global socialist transformation would be a massive understatement. Despite terribly unjust and horrendous material conditions for debtors around the world, a debtors' movement has not, and will not, spontaneously emerge. Even though there are increased calls for debt forgiveness from countries in the Global South, and even political campaigns in the United States, and in certain countries of Europe, that include student debt cancellation in their platforms, ${ }^{6}$ we are still far removed from having a debt movement that can wield sufficient strength to counter the force, and shake the foundations of, the debt economy. For this reason, a sustained campaign of political education on debt is fundamental to any future success of debtors' movements present, and those to come. Debt resistors, and a collective debt movement, must be cultivated via a combination and intersection of political education, base building, and direct actions coordinated over time.

What I have argued above, is that $\mathrm{P} 4 \mathrm{wC}$, conceptualized as a type of educational debt counter-conduct, can play a modest role in shaping the type of oppositional debt consciousness and ethics needed in debt resistance movements. Though $\mathrm{P} 4 \mathrm{wC}$ is most often practiced within educational institutions, I would like to conclude this piece with a suggestion that nascent debt resistance organizations/movements should include $\mathrm{P} 4 \mathrm{wC}$ methodologies in their own political education efforts. There is precedence for this move. As one of the founding members of the Occupy University, a free "people's university" founded during the Occupy Wall Street uprising in New York (2011), I played a role in introducing $\mathrm{P} 4 \mathrm{wC}$ to a political education committee that worked on developing pedagogies for the movement. Gradually, P4wC came to have a major influence on the training sessions, held in Trump Tower every Thursday night for nearly a year, for what came to be known as Horizontal Pedagogy (Backer, Bissen,

\footnotetext{
${ }^{6}$ For instance, Bernie Sanders promised throughout his campaign for the United States presidency to cancel all student debt and make public universities tuition free. The Movement for Black Lives Platform explicitly calls for debt abolition. See: https://m4bl.org/policy-platforms/
} 
cultivating oppositional debt ethics and consciousness: philosophy for/with children as counter-conduct in the neoliberal debt economy

Laroche, Perisic, \& Wozniak, 2017). This pedagogy was subsequently used in a variety of Occupy spaces and events, most notably, in events and campaigns organized by another Occupy subcommittee, Strike Debt. To a certain degree, this current article would have been impossible to write were it not for my experience with both Pw4C in the periphery of Rio de Janeiro, ${ }^{7}$ and Horizontal Pedagogy on the streets of New York City. My own political education on debt is in part a direct result of HP sessions on debt realities. And on one level, we might say that unless debtors' movements make use of pedagogical practices that counter-interpellate indebted subjectivity, and cultivate people willing to do battle against the forces of debt, we will all remain imprisoned by the debts we owe.

COVID is not the only virus that plagues the world. Late stage financial capitalism is making us all sick. $\mathrm{P} 4 \mathrm{wC}$ has a counter-conduct role to play in helping us break the bonds of debt that bind so many to life a misery. The question, is whether it will be used to make that intervention...

\section{references}

American Association of University Women, (2017). Deeper in debt: Women and student loans. https://www.aauw.org/resources/research/deeper-in-debt/.

Backer, D., Bissen, M., Laroche, J., Perisic, A., Wozniak, J., What is horizontal pedagogy? A discussion on dandelions. In: Haworth, R. H., \& Elmore, J. M. (Eds.) Out of the ruins: The emergence of radical informal learning spaces (195-222). Oakland, CA: PM Press.

Balibar, E. (2013). Politics of Debt, Postmodern Culture Vol. 23 (3). 1-35. Retrieved 9.14.15. from Project Muse Database.

Brusi, R., Bonilla, Y., and Godreau, I., (9/20/2018). When disaster capitalism comes for the University of Puerto Rico. The Nation. https://www.thenation.com/article/archive/when-disaster-capitalism-comes-forthe-university-of-puerto-rico/).

Brown, W. (2015). Undoing the demos: Neoliberalism's stealth revolution. New York: Zone Books.

Caffentzis, G. (2013). Reflections on the history of debt resistance: The case of El Barzón. Retrieved from http:/ / strikedebt.org/elbarzon/.

Caffentzis, G. (2016). Everyday life in the shadow of the debt economy. In: Schraube E. \& Højholt (Eds.) Psychology and the conduct of everyday life (176-192). London: Routledge.

\footnotetext{
${ }^{7}$ Much of my P4wC formation comes from my experience of working with the Center for the Study of Philosophy and Infancy (NEFI), at the State University of Rio de Janeiro (UERJ) for over six years on a variety of initiatives.
} 
Cavallero, L. and Gago, V. (2019). Una lectura feminista de la deuda: ¡Vivas, libres y desendeudadas nos queremos!. Buenos Aires: Fundación Rosa Luxemburgo.

Davidson, A.I .(2011). In praise of counter-conduct. History of the Human Sciences. 24(4): 25-41.

De Sousa-Santos, B. (2016). Epistemologies of the South and the future. From the European South vol.1. 17-29.

Retrieved from: http://www.boaventuradesousasantos.pt/media/Epistemologies\%20of\%20the \%20so uth\%20and\%20the\%20future_Poscolonialitalia_2016.pdf.

Derrida, J. (1992). Given time: I. Counterfeit money. (P. Kamuf, Trans.) Chicago: University of Chicago Press.

Donnelly-Derovan, C. (2019). When the children leave: What's left after a mass exodus of young people from Puerto Rico? The Hechinger Report. https:/ / hechingerreport.org/when-the-children-leave-whats-left-after-a-massexodus-of-young-people-from-puerto-rico/)

Dussel, E. (1988). Ethics and community. (Robert R. Barr, Trans.) Maryknoll, NY: Orbis Books.

Dussel, E. (2013). Ethics of liberation in the age of globalization and exclusion. (E. Mendieta, C. P. Bustillo, Y. Angulo \& N.M. Torres, Trans.) Durham, NC: Duke University Press.

Foucault, M. (2007). Security, territory, population: Lectures at the College de France 1977-1978. (G. Burchell, Trans.) New York, NY: Palgrave MacMillan.

Foucault, M. (2008). The birth of biopolitics: Lectures at the College de France 1978-1979. (G. Burchell, Trans.). New York, NY: Palgrave MacMillan.

Freire, P. (1989). A importância do ato de ler: Em três artigos que se completam. São Paulo: Autores Associados.

Freire, P. (2001). Política e educação. São Paulo: Cortez.

Freire, P. (2017). Professora sim, tia não: cartas a quem ousa ensinar. São Paulo: Olho d'Água.

Graeber, D. (2012). Debt: The first 5,000 years. Brooklyn, NY: Melville House.

Gregory, M. (2011). Philosophy for children and its critics: A Mendham dialogue. Journal of Philosophy of Education, 45(2). 199-219.

Hartman, S. V. (1997). Scenes of subjection: Terror, slavery, and self-making in Nineteenth-Century America. Oxford: Oxford University Press.

Hartman, S. (2007). Lose your mother: A journey along the Atlantic slave route. Farrar, Straus and Giroux: New York.

Hartman, S. (2019). Wayward lives, beautiful experiments: Intimate histories of social upheaval. New York: W.W. Norton.

Harvey, D. (2005). A brief history of neoliberalism. Oxford: Oxford University Press.

Institute for New Economic Thinking. (7/21/2020). Debt talks episode 1: The secular rise of debt. https://www.ineteconomics.org/ events/debt-talks-the-secular-rise-of-debt.

International Council of Philosophical Inquiry with Children, Biennial Conference, (2019). Philosophy for/with Children and the Citizen-Agent: Main Topic. https:/ / eventos.uniminuto.edu/20862/section/12843/icpic-2019.html).

Kennedy, D. and Kohan, W.O. (2014). school and the future of scholé: A preliminary dialogue. childhood E philosophy, 10(19), 199-216.

Laverty, M. and Gregory, M. (2017). pragmatism and the unlearning of learnification. childhood $\mathcal{E}$ philosophy, 13(28), 521-536.

Lazzarato, M. (2012). The making of the indebted man. (J.D. Jordan, Trans.). Los Angeles, CA: Semiotext(e).

Lazzarato, M. (2015). Governing by debt. (J.D. Jordan, Trans.). Los Angeles, CA: Semiotext(e). 
cultivating oppositional debt ethics and consciousness: philosophy for/with children as counter-conduct in the neoliberal debt economy

Marx, K. (1845). Theses on Feuerbach. (C. Smith, Trans.). Retrieved from: https://www.marxists.org/archive/marx/works/1845/theses/index.htm.

Philadelphia School District Office of Management \& Budget. (2020). Philadelphia School District 2019-2020 Adopted Operating Budget: Quick Budget Facts. https://www.philasd.org/budget/budget-facts/quick-budget-facts/.

Rich, A. (1987). Dreamwood. The Poetry Foundation. Retrieved on 31March 2017 from https://www.poetryfoundation.org/poetrymagazine/poems/detail/55629.

Rizzo, E. (10/31/2019). Pa. quietly reverses 'lunch shaming' ban as school district debt grows. WHYY PBS. https://whyy.org/articles/pa-quietly-reverses-lunch-shaming-ban-asschool-district-debt-

grows /\#: :text=Superintendent $\%$ 20William \%20Harner $\% 20$ says $\% 20$ lunch,peak $\% 20$ of $\% 20 \% 2427 \%$ 2C000\%20last \% 20year.

Ross, A. (2013). Creditocracy and the case for debt refusal. New York: OR Books.

Sharp, A.M. (2009). The child as critic. In: Marsal, E., Dobashi, T., Weber, B. Children philosophize worldwide: Theoretical and practical concepts. 201-209.

Streeck, W. (2017). Buying time: The delayed crisis of democratic capitalism. (P. Camiller and D. Fernbach, Trans.) New York: Verso.

Way, J. (2019). On Philadelphia's toxic schools. Remarks at Community Meeting to Heal our Toxic Schools. Philadelphia, PA.

Wozniak, J.T. (2017). Towards a rhythmanalysis of debt dressage: Education as rhythmic resistance in everyday indebted life. Policy Futures in Education. 0(0). 1-14.

received in: 26.07 .2020

approved in: 24.08 .2020 